\title{
Instrumentation for Engineers
}




\section{Other Macmillan titles of related interest}

Mechanical Reliability, second edition

A. D. S. Carter

Transducers for Microprocessor Systems

J. C. Cluley

Elementary Engineering Mechanics

G. E. Drabble

Principles of Engineering Thermodynamics, second edition

E. M. Goodger

An Introduction to Electrical Instrumentation and Measurement Systems

B. A. Gregory

Polymer Materials: An Introduction for Technologists and Scientists

Christopher Hall

Principles of Diagnostic $X$-ray Apparatus

D. R. Hill

Introduction to Engineering Materials, second edition

V. John

Optoelectronic Devices and Optical Imaging Techniques

Douglas A. Ross

Strength of Materials, third edition

G. H. Ryder

Mechanics of Machines

G. H. Ryder and M. D. Bennett

Engineering Heat Transfer, second edition

J. R. Simonson

Introduction to Internal Combustion Engines

Richard Stone

Sensors and Transducers

Mike Usher

Essential Solid Mechanics-Theory, worked examples and problems

B. W. Young 


\title{
Instrumentation for Engineers
}

\author{
J. D. Turner \\ BSc (Phys), PhD, CEng, MIEE \\ Department of Mechanical Engineering \\ University of Southampton
}

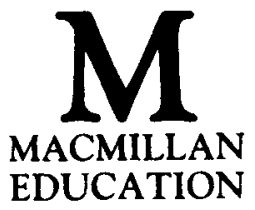


All rights reserved. No reproduction, copy or transmission of this publication may be made without written permission.

No paragraph of this publication may be reproduced, copied or transmitted save with written permission or in accordance with the provisions of the Copyright Act 1956 (as amended), or under the terms of any licence permitting limited copying issued by the Copyright Licensing Agency, 33-4 Alfred Place, London WC1E 7DP.

Any person who does any unauthorised act in relation to this publication may be liable to criminal prosecution and civil claims for damages.

First published 1988

Published by

MACMILLAN EDUCATION LTD

Houndmills, Basingstoke, Hampshire RG21 2XS

and London

Companies and representatives throughout the world

British Library Cataloguing in Publication Data

Turner, J. D.

Instrumentation for engineers.

1. Instrumentation

I. Title

$620^{\prime} .0044$

ISBN 978-0-333-44551-8

ISBN 978-1-349-19508-4 (eBook)

DOI 10.1007/978-1-349-19508-4 
For Caroline and Jack 


\section{Contents}

Preface

Acknowledgements $\quad$ xiii

1 The Performance of Instrumentation Systems 1

Introduction 1

Generalised instrumentation design 3

The performance of instrumentation systems 6

Error analysis $\quad 6$

2 Sensors and Transducers 13

Introduction $\quad 13$

Displacement sensing $\quad 13$

Velocity sensing $\quad 21$

Acceleration sensing $\quad 24$

Strain measurement 25

Flow sensors $\quad 29$

Temperature sensors $\quad 32$

Optical sensors $\quad 35$

Acoustic sensors $\quad 38$

Hall effect sensors $\quad 39$

3 Signal Conditioning 41

Introduction 41

Bridge circuits $\quad 42$

Operational amplifier signal conditioning circuits $\quad 55$

$\begin{array}{ll}\text { Analysing op-amp circuits } & 62\end{array}$ 
4 Analogue Filters $\quad 79$

$\begin{array}{lr}\text { Introduction } & 79\end{array}$

Filter order $\quad 81$

Filter class $\quad 82$

Operational-amplifier filters $\quad 84$

Special-purpose filter devices $\quad 95$

5 Signal Conversion $\quad 102$

$\begin{array}{ll}\text { Introduction } & 102\end{array}$

Digital and analogue conversion fundamentals 103

Digital-to-analogue converters 105

Frequency-to-voltage converters $\quad 109$

$\begin{array}{ll}\text { Sample-and-hold devices } & 109\end{array}$

$\begin{array}{lr}\text { Analogue-to-digital converters } & 110\end{array}$

Analogue multiplexers $\quad 115$

$\begin{array}{ll}\text { Example design } & 116\end{array}$

6 Digital Circuits and Microprocessor Interfacing 118 $\begin{array}{ll}\text { Introduction } & 118\end{array}$

$\begin{array}{ll}\text { Digital device families } & 118\end{array}$

Combinational logic, gates and Boolean algebra $\quad 121$

$\begin{array}{ll}\text { Sequential logic circuits } & 125\end{array}$

Digital systems interfacing $\quad 130$

$\begin{array}{lr}\text { Number codes } & 135\end{array}$

$\begin{array}{ll}\text { Microprocessors } & 138\end{array}$

Example interface designs $\quad 144$

$\begin{array}{ll}\text { Communication standards } & 157\end{array}$

7 Frequency Domain Analysis 159

$\begin{array}{lr}\text { Introduction } & 159\end{array}$

The modal domain $\quad 164$

Waterfall diagrams $\quad 167$

$\begin{array}{ll}\text { Vector response diagrams } & 168\end{array}$

$\begin{array}{ll}\text { Fourier analysis } & 170\end{array}$

$\begin{array}{ll}\text { Fourier series } & 170\end{array}$

$\begin{array}{ll}\text { The Fourier Transform } & 177\end{array}$

8 Practical Spectrum Analysis $\quad 180$

$\begin{array}{ll}\text { Introduction } & 180\end{array}$

Analogue analysers $\quad 180$

Digital analysers $\quad 182$

$\begin{array}{lr}\text { The Fast Fourier Transform } & 184\end{array}$

Aliasing and Shannon's Sampling Theorem 188 
$\begin{array}{ll}\text { Windowing } & 190\end{array}$

Choice of window 195

Glossary of FFT analyser terminology 199

9 Correlation and Spectral Analysis 203

$\begin{array}{ll}\text { Introduction } & 203\end{array}$

Signal classification $\quad 203$

Autocorrelation $\quad 205$

Interpreting autocorrelation diagrams $\quad 208$

$\begin{array}{ll}\text { Cross-correlation } & 213\end{array}$

Interpreting cross-correlation functions $\quad 215$

$\begin{array}{lr}\text { Bibliography and Further Reading } & 217\end{array}$

$\begin{array}{lr}\text { Index } & 219\end{array}$ 


\section{Preface}

The science (or even the art!) of instrumentation is of fundamental importance to engineers, scientists and medical workers. Instruments are the eyes and ears of the technologist. (His nose is reserved for detecting the effects of excess current.) Without sensors and their associated signal processing systems there would be no modern transport, no National Grid distributing electricity, and anyone unlucky enough to fall ill would be offered only the most primitive medical treatment. The progress that has been made in almost all areas of technology can be seen in terms of the rate at which the necessary instrumentation has been developed. For example, in recent years many improvements have been made to the performance of the internal combustion engine. More and more power has been squeezed out of smaller and more economic engines. One of the reasons is that in the last few years sensors have been developed which allow investigations to be made of the way in which the flame front spreads inside a cylinder after ignition. This work has led to a redesign of the geometry of the inlet valves and the piston, and more efficient engines are the result.

The process of instrumentation is often considered solely in terms of the sensors used and their associated electronics. However, there are two steps involved in making any measurement. These are, first, getting the data, which is where sensors and electronics are used, and second, analysing it. The analysis may simply consist of an assessment of the errors, or may involve the application of some more complicated technique such as Fourier or correlation analysis. The important point is that some form of signal analysis is almost always necessary. The type of analysis to be applied may well have implications for the kind of sensors used, or vice versa. Thus, an instrumentation system should be designed or used with due regard to the expectations that the user has of the results. 
In view of the importance of instrumentation, it is vital that engineers and scientists have a good working knowledge of the principles involved in measurement and analysis. If the best possible performance is to be had from a measurement system then its weaknesses must be thoroughly understood, as well as its strong points. It is often said of electronic systems and devices that the most important features to look out for are the ones that the manufacturer has NOT included on the data sheet!

The basis of this book is a course in instrumentation which I give to final year mechanical engineering undergraduates. This course presents instrumentation from the viewpoints of both electronics and signal analysis. The sensors and electronic circuits likely to be needed by a final year student project and for postgraduate research are comprehensively covered. Three chapters are devoted to methods of time and frequency domain analysis, and suggestions for further reading on some of the more specialised techniques are given in the bibliography. It is therefore a suitable university text for students of engineering, science or medicine who are seeking a practical guide to instrumentation. It is also hoped that the book will be of use to practising engineers in general.

Finally, some words of thanks. I would like to record my gratitude to my friend and colleague Tony Pretlove, who first showed me the fascination of engineering, and turned a reluctant physicist into a happy engineer. Thanks are also due to Martyn Ramsden, who read the manuscript and offered many helpful suggestions, and to Professor Roy Farrar of Southampton University who encouraged the work. The text was typed and corrected by myself on that wonderful thing, a word-processor program on a microcomputer. Without the aid of this software it would have been impossible to keep the end result in View.

Hear ye not the hum of mighty workings?

Keats: to Haydon 


\section{Acknowledgements}

The author wishes to thank Professor R. Farrar, Head of the Department of Mechanical Engineering at Southampton University, for his encouragement regarding the lecture courses on which this book is based, and $\mathrm{Mr} \mathrm{A}$. Munday and Dr G. Pitts, also of Southampton University, for their many helpful suggestions about the content of the book.

Permission for the reproduction of figures and tables is acknowledged from the following bodies:

The Parker Publishing Company Inc for tables 4.1, 4.2, 4.3, 4.4, 4.5, 4.6, 4.7 and 4.8. E. G. and G. Reticon for the datasheets for the RF5609, RM5604, RM5605 and RM5606, which appear at the end of chapter 4. Texas Instruments Ltd for the datasheet on the 741 op-amp at the end of chapter 3. Brüel and Kjaer (UK) Ltd for figures 2.11, 2.13 and 8.21. Butterworth \& Co (Publishers) Ltd for figures 6.23 and 6.24.

Every effort has been made to trace all copyright holders but if any have been inadvertently overlooked the publishers will be pleased to make the necessary arrangement at the first opportunity. 